\title{
Antigenicity of Desamido-Insulin and Monocomponent Insulin
}

\author{
T. Kasama ${ }^{1}$, Y. Iwata ${ }^{1}$, K. Oshiro ${ }^{1}$, M. Uchida ${ }^{1}$, Y. Sakaguchi ${ }^{1}$, K. Namie ${ }^{2}$ and M. Sugiura ${ }^{3}$ \\ ${ }^{1}$ Research Laboratory, Kodama Ltd, Tokyo, ${ }^{2}$ Saitama College of Health, Urawa and ${ }^{3}$ Gifu College of Pharmacy, Gifu, Japan
}

Summary. No consensus about the antigenicity of monocomponent insulin has yet been reached. We have therefore administered different insulin preparations to rabbits and rats to determine $\lg \mathrm{g}$ and $\operatorname{lgE}$ antibody production. The preparations used were porcine monocomponent insulin, conventional bovine and porcine insulin powders, porcine $b$-component and synthesised porcine mono-desamidoinsulin and hexa-desamido-insulin. In rabbits, porcine b-component was the most antigenic preparation, followed by conventional bovine and porcine insulins. No antibody production was observed with the other preparations. In rats the $60 \mathrm{~h}$ passive cutaneous anaphylaxis test showed virtually no insu$\operatorname{lin} \operatorname{lgE}$ antibody production in response to porcine monocomponent insulin. However, if porcine b-component or porcine hexa-desamido-insulin was employed both for sensitisation and as the challenging antigen, positive skin reactions were observed with demonstration of insulin $\lg E$ antibodies. Our results confirm the low antigenicity of the pharmaceutical preparation of porcine monocomponent insulin and suggest that porcine hexa-desamido-insulin and porcine b-component administration may result in the production of reagin-type antibodies.

Key words: $\operatorname{lgG}$ antibody, reaginic antibody, antigenicity of monocomponent insulin, desamido-insulin, porcine b-component, passive cutaneous anaphylaxis test, insulin

Some animal and human studies have shown monocomponent insulin (MC-insulin) [1] to be of low antigenicity $[2,3]$, while others have suggested that it is more antigenic in diabetic subjects [4]. A previous investigation [5] showed that $\mathrm{MC}$-insulin may be deamidated during storage to desamido-insulin. It is thus possible that this conversion product is an important cause of the insulin antibody generation seen in subjects receiving $\mathrm{MC}$-insulins. We have therefore administered desamido-insulin to rabbits for prolonged periods to investigate insulin antibody production.

As the generation of $\operatorname{lgE}$ antibodies against insulin has been reported in both man and animals $[6,7]$, we have also studied the production of such antibodies in animals immunized with a variety of insulin preparations.

\section{Materials and Methods}

\section{Insulin Preparations}

The following preparations were employed:

1) Porcine MC-insulin pharmaceutical preparation (Insulin Novo Actrapid) (PMC-A)

2) Conventional bovine insulin powder (recrystallised bovine insulin containing pro-insulin-like substances and arginine insulin in amounts of approximately $3 \%$ ) (CB-I)

3) Conventional porcine insulin powder (recrystallised porcine insulin containing proinsulin-like substances and arginine insulin in amounts of approximately $3 \%$ ) (CP-I)

4) Porcine b-component insulin (PB-C)

5) Porcine MC-insulin powder (PMC-P)

6) Porcine mono-desamido-insulin (PMD-I) was prepared in our Iaboratories by a modification of the method of Sundby [8]. Porcine MC-insulin solution (1.6 mg of PMC-P in $1 \mathrm{ml}$ of $0.1 \mathrm{~mol} / \mathrm{t}$ $\mathrm{HCl}$ ) was incubated at $37^{\circ} \mathrm{C}$ for 7 days. Samples were removed every $24 \mathrm{~h}$ and the $\mathrm{pH}$ adjusted to the isoelectric point with $0.1 \mathrm{~mol} / 1 \mathrm{NaOH}$. After $24 \mathrm{~h}$ storage at $4{ }^{\circ} \mathrm{C}$, the samples were centrifuged at $3000 \mathrm{rev} / \mathrm{min}$ and the precipitate washed several times with $0.001 \mathrm{~mol} / \mathrm{l}$ zinc acetate solution before lyophilisation. Figure 1 shows the result of polyacrylamide disc gel electrophoresis (PAGE) [9]. Fifty percent desamido-insulin was prepared by this method, but because deamidation progressed very rapidly, mono-desamido-insulin was not isolated. This preparation was incubated for $24 \mathrm{~h}$ at $37^{\circ} \mathrm{C}$ and used as PMD-I.

7) Porcine hexa-desamido-insulin (PHD-I) was prepared by a modification of the method of Sundby [8]. The solvent was 0.3 $\mathrm{mol} / 1 \mathrm{HCl}$, the incubation temperature was $37^{\circ} \mathrm{C}$ and the incubation period 13 days. Electrophoretograms are shown in Figure 1. 




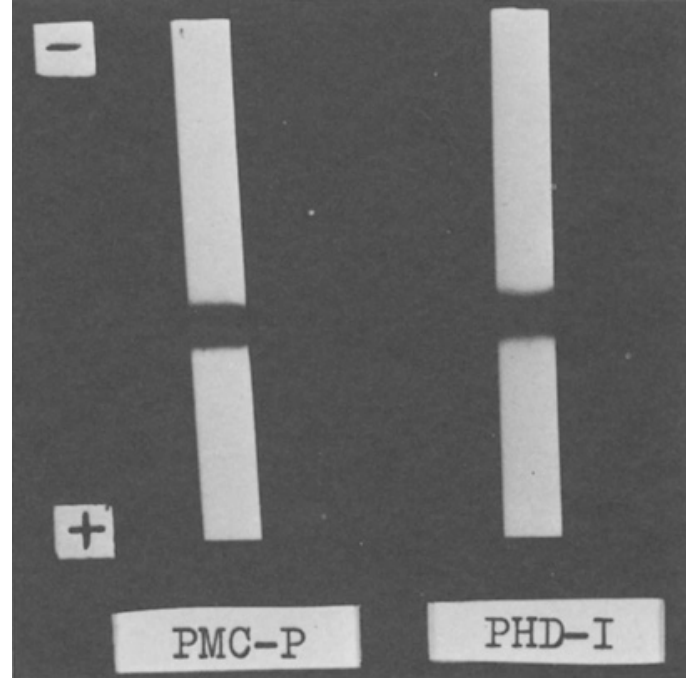

Fig. 2. $0.1 \%$ Sodium dodecyl sulphate $15 \%$ polyacrylamide disc-gel electrophoretograms of PMC-P and PHD-I. Molecular weight of PHD-I is similar to that of PMC-P

Fig. 1 a and b. $7.5 \%$ Polyacrylamide disc-gel electrophoretograms for the preparation of PMD-I and PHD-I. a PMC-P was dissolved in $0.1 \mathrm{~mol} / 1 \mathrm{HCl}$ and incubated at $37^{\circ} \mathrm{C}$ for the days indicated. The material incubated for 1 day was PMD-I. b PMC-P was dissolved in $0.3 \mathrm{~mol} / 1 \mathrm{HCl}$ and incubated at $37^{\circ} \mathrm{C}$ for the days indicated. The material incubated for 13 days was hexadesamido-insulin
Identification of Porcine Hexa-desamido-insulin. To verify that the above preparation was indeed hexa-desamido-insulin the following procedure was followed. Sodium dodecyl sulphate PAGE was performed [10] on $50 \mu \mathrm{g}$ of PHD-I using PMC-P as a standard. Amino acids were analysed by a Hitachi Model KLA- 5 analyser with hydrolysis for $24 \mathrm{~h}$ [11]. Amide nitrogen [12] was compared with that of PMC-P. The decomposition point was determined [13]. Specific optical rotation was measured with a polarimeter (Jasco DIP-4, Tokyo, Japan) using $20 \mathrm{mg}$ of the preparation in $20 \mathrm{ml}$ of $0.01 \mathrm{~mol} / 1 \mathrm{HCl}$. Absorbance at $276 \mathrm{~mm}$ was determined with an UV-VIS Spectrophotometer (Hitachi, model 239). Isoelectric point was determined by gel electrofocussing. Zinc content was determined with an Atomic Absorption/Flame Spectrophotometer (Shimazu, AA-640-13), using $7.5 \mathrm{mg}$ of the preparation dissolved in $2 \mathrm{ml}$ of $0.01 \mathrm{~mol} / 1 \mathrm{HCl}$. A Mitsubishi Moisturemeter (model CA-02) was used to measure water content. Biological activity was assayed [14].

\section{Animals}

Domestic white male rabbits weighing between 2.0 and $2.5 \mathrm{~kg}$ (Japan Medical Science Laboratory, Tokyo) were used after being maintained under consistent conditions for more than one week.
Wistar strain male rats with an average body weight of $150 \mathrm{~g}$ were used (Saitama Animal Suppliers, Sugito, Japan). Hartley strain male guinea pigs with body weights ranging between 250 and $350 \mathrm{~g}$ (Matsumoto Experimental Company, Chiba, Japan) were employed for the passive cutaneous anaplylaxis (PCA) test.

\section{Other Materials}

Commercially available Bordetella pertussis (Chiba Serum Institute, Chiba, Japan), Streptolysin-O (Eiken Chemical Co, Tokyo) and preserved blood of rabbits (Nippon Bio-test Laboratories, Tokyo) were purchased. Other chemicals used were of reagent grade.

\section{Immunisations}

Detection of $\operatorname{Ig} G$ Antibodies. Rabbits were randomly divided into seven groups of six animals each and six groups were injected subcutaneously between the shoulder blades every third day for 180 days with $40 \mathrm{ug} \mathrm{ml}^{-1} \mathrm{~kg}^{-1}$ of PMC-A, CB-I, PB-C, PMD-I or PHD-I each dissolved in $1 \mathrm{~g} / \mathrm{l}$ acetate buffer of $\mathrm{pH} 7.4$. Group 7 received $1 \mathrm{ml} / \mathrm{kg}$ of the buffer alone and acted as control. At 45 - 
Table 1. Amino acid analysis of porcine hexa-desamido-insulin and porcine monocomponent insulin

\begin{tabular}{|c|c|c|c|c|c|c|c|c|c|c|c|c|c|c|c|c|}
\hline & Asp & Thr & Ser & Glu & Pro & Gly & $\mathrm{Ala}$ & $\mathrm{Val}$ & Cys $/ 2$ & Ile & Leu & Tyr & Phe & Lys & His & Arg \\
\hline PHD-I & 2.84 & 2.26 & 3.32 & 7.10 & 0.71 & 3.81 & 2.00 & 3.75 & 2.90 & 1.90 & 6.20 & 3.87 & 3.00 & 0.92 & 1.85 & 0.96 \\
\hline PMC-P & 3.02 & 1.86 & 2.79 & 6.98 & 0.95 & 3.91 & 2.03 & 3.87 & 3.13 & 1.65 & 6.24 & 3.79 & 3.00 & 1.04 & 1.84 & 0.97 \\
\hline
\end{tabular}

Each value represents the molar ratio to phenylalanine (Phe) and is the mean of three experiments

Table 2. Physical characteristics of porcine hexa-desamido-insulin (PHD-I) and porcine monocomponent insulin (PMC-P)

\begin{tabular}{lll}
\hline & PHD-I & PMC-P \\
\hline Decomposition temperature & $226-228^{\circ}$ & $227-228^{\circ}$ \\
$\alpha^{20}$ & $-43.10^{\circ}$ & $-25.5^{\circ}$ \\
$\mathrm{E}_{1 \mathrm{c}}^{\mathrm{o}}(276 \mathrm{~nm})$ & 11.59 & 11.17 \\
Isoelectric point & $4.68-4.73$ & $4.84-4.89$ \\
$\mathrm{Zn}(\%)$ & 0.53 & 0.40 \\
$\mathrm{H}_{2} \mathrm{O}(\%)$ & 9.0 & 7.0 \\
Biological activity & 69.0 & 100 \\
\hline
\end{tabular}

${ }^{a}$ Bioassay was as described in reference [14] (see text). PHD-I had $69 \%$ of the biological activity of PMC-P

day intervals, approximately $7 \mathrm{ml}$ of blood were drawn from the marginal ear vein for determination of insulin binding antibody and the PCA test [15] using guinea pigs. Insulin-binding antibodies were assayed according to the polyethylene-glycol precipitation method of Nakagawa et al. [16].

Detection of $\lg E$ antibodies: Rats were randomly divided into seven groups of eight rats each and the members of six groups were sensitised with one of the insulin preparations used above. Appropriate amounts of each preparation were dissolved in $0.1 \mathrm{ml}$ saline $(1 \mathrm{mg} / \mathrm{ml})$, and $0.9 \mathrm{ml}$ aluminium gel $(20 \mathrm{mg} / \mathrm{ml})$ and $0.5 \mathrm{ml}$ Bordetella pertussis $\left(2 \times 10^{11}\right.$ cells $\left./ \mathrm{ml}\right)$ were added [17]. In group 7 which acted as control, the animals received injections consisting of $0.1 \mathrm{ml}$ of $0.154 \mathrm{~mol} / 1$ saline, $0.9 \mathrm{ml}$ aluminium gel and $0.5 \mathrm{ml}$ Bordetella pertussis. At 5 -day intervals, beginning with day 5 after the first immunisation and continuing for 40 days, approximately $1 \mathrm{ml}$ of blood was obtained by cardiac puncture and subjected to PCA assay. Antiserum ( $0.1 \mathrm{ml}$ of each) was injected intradermally into the shaved backs of male Wistar rats and, $60 \mathrm{~h}$ later, as the challenging antigen, porcine monocomponent insulin (PMC-P) dissolved in saline $(1 \mathrm{mg} / \mathrm{ml})$ and $1 \mathrm{ml}$ of $0.1 \%$ Evans blue dye were injected into the tail vein. After $30 \mathrm{~min}$ the skin was reflected and dye extravasation was determined. Animals in which the blue spot was larger than $5 \times 5 \mathrm{~mm}$ were recorded as reaction positive.

In different PCA tests, the preparation used for sensitisation of the animal was also used as the challenging antigen. It was injected IV and the antiserum was administered intradermally.

\section{Histological Studies}

At the end of 180 days all the rabbits were exsanguinated and the livers and kidneys removed for histological examination [18].

Blood obtained before and after the various insulin administrations was examined by the antistreptolysin-O test [19].

\section{Statistical Analysis}

Statistical analysis was carried out with Student's t-test.

\section{Results}

\section{Identification of Porcine Hexa-desamido-insulin (PHD-I)}

1) Sodium dodecyl sulphate PAGE: Simultaneous examination of PHD-I and PMC-P (Fig. 2) revealed similarity of electrophoretic mobilities and hence molecular weights.

2) Amino acid analysis: The amino acid compositions were similar (Table 1).

3) Amide nitrogen determination: The amide nitrogen value of PMC-P was 5.88 amide groups per mole of insulin, and for PHD-I $1 \times 10^{-3}$. These results confirm PHD-I to be hexa-desamido-insulin in which all the amide residues of PMC-P had been deamidated.

4) The physical properties of PHD-I and PMC-P are compared in Table 2 and show similarity of decomposition and isoelectric points and of zinc content.

\section{Detection of IgG Antibodies in Rabbits}

Polyacrylamide disc gel electrophoresis results of the six different preparations used in the study showed a clear difference in purity (Fig. 3). When the mean body weight changes of the six experimental rabbit groups were compared with each other and with the control group, no differences were noted.

The changes in serum insulin-binding antibodies are shown in Fig. 4. On day 45 after the first immunisation, a significant increase in insulin-binding antibody was observed in the PB-C group as compared with the control $(p<0.05)$ and the percentage binding of ${ }^{125} \mathrm{I}$-insulin $(\mathrm{B} / \mathrm{T})$ in this group continued to increase, reaching $20 \%$ by day 180 . In the CB-I and CP-I groups, an increase in insulin-binding antibodies was observed on day 90 , reaching $14.7 \%$ and $12.9 \%(\mathrm{~B} / \mathrm{T})$ respectively by day 180 . No such increases were observed in the PMC-A, PMD-I and 


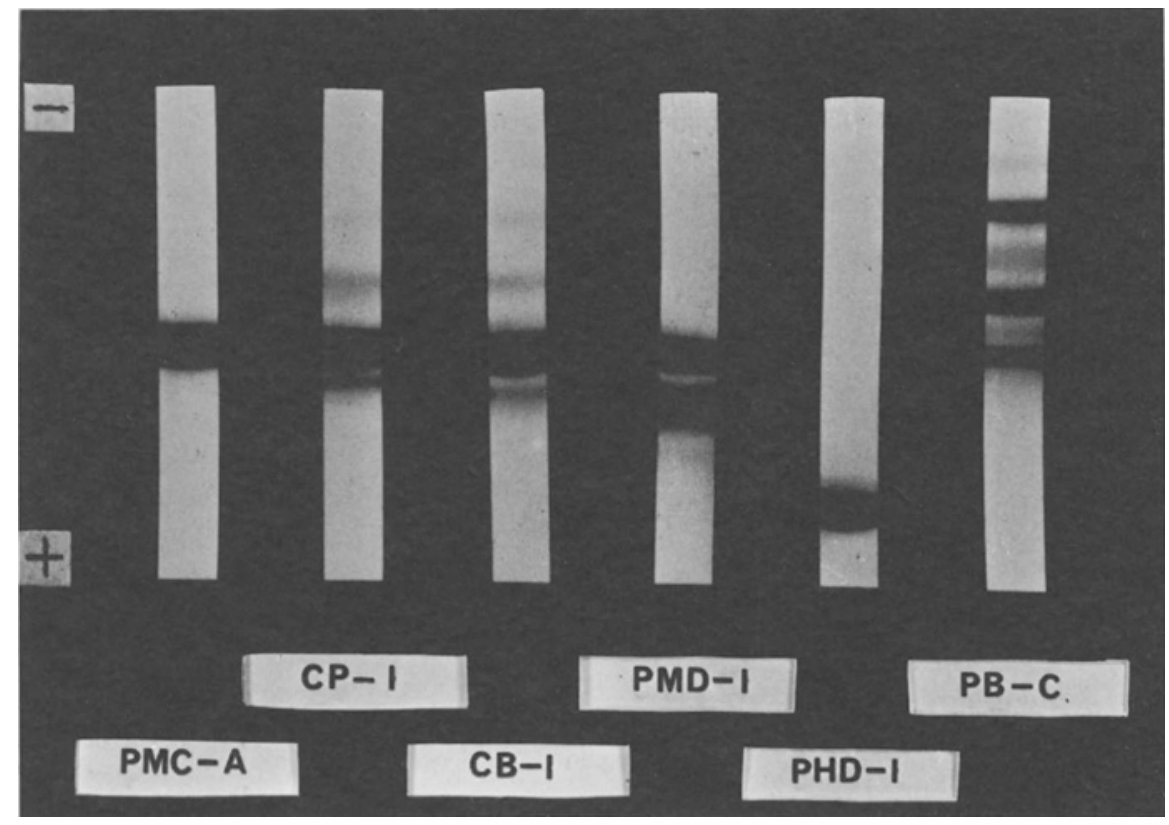

Fig. 3. 7.5\% Polyacrylamide disc-gel electrophoretograms of the materials used in this study, showing their different purity. $\mathrm{PMC}-\mathrm{A}, \mathrm{CP}-\mathrm{I}, \mathrm{CB}-\mathrm{I}$, PMD-I, PHD-I and PB-C represent insulin Novo Actrapid, conventional porcine insulin, conventional bovine insulin, porcine mono-desamido-insulin, porcine hexa-desamido-insulin and porcine b-component respectively

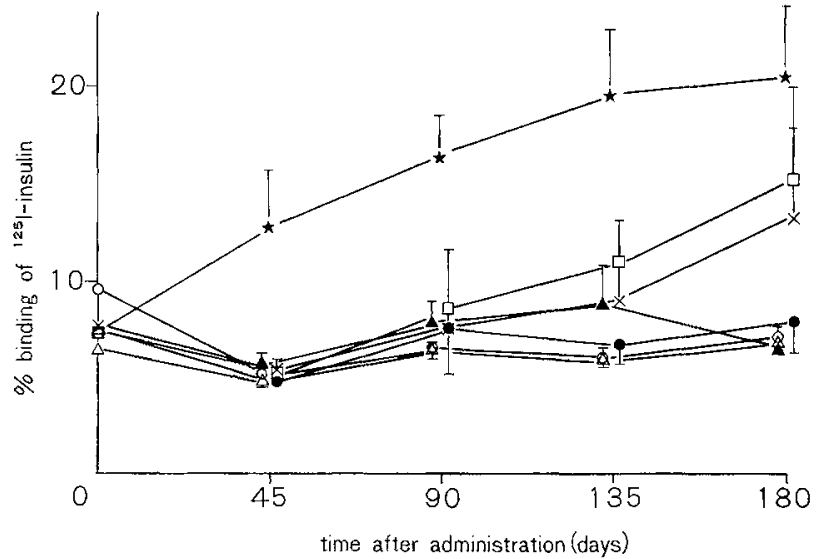

Fig. 4. Changes of serum insulin binding antibody in rabbits administered subcutaneously with PMC-A $(\mathrm{O}-\mathrm{O}), \mathrm{CP}-\mathrm{I}$ $(\times-\times), \quad$ CB-I $(\square-\square), \quad$ PMD-I $(\boldsymbol{\Delta}-\mathbf{A}), \quad$ PHD-I $(\bullet-\bullet)$, PB-C $(\star-\downarrow)$ ) or control $(\triangle-\triangle)$. Vertical bars represent the standard error of the mean $(n=6)$

PHD-I groups and there were no differences between these groups and the control group throughout the period of insulin administration.

All PCA tests were negative.

\section{Histological Study}

There were no differences between livers from the experimental groups and those of control rabbits. The same was true for the kidneys with the exception of organs from the PB-C group. In these kidneys,
$50 \%$ of the glomeruli showed hypertrophy of the glomerular basement membrane and there was narrowing of the glomerular capsular space. Less than $5 \%$ of glomeruli in the other groups exhibited these changes.

Results of the antistreptolysin-O test were negative.

\section{Detection of IgE Antibodies in Rats}

When PMC-P was used as the challenging antigen, the $60 \mathrm{~h}$ PCA test, examined at 5-day intervals, was negative in all animals in all groups with the exception of one rat each in the PHD-I and PB-C groups. In these rats, PCA was positive on day 10 and negative thereafter. However, when the challenging material were changed to the same antigen as that used for sensitisation, positive PCA was noted at 15 days after the beginning of immunisation, especially in the PHD-I and PB-C groups. The PCA titres in the PHD-I group was $1: 2$ and, in the PB-C group, $1: 8$.

\section{Discussion}

The antigenicity of monocomponent insulin was examined in rabbits administered with the preparation at 3-day intervals for a period of 180 days. No adjuvant was used, in order to approximate clinical conditions as closely as possible. No obvious production of IgG antibodies against MC-insulin was observed. However, in animals receiving the porcine b-component, the production of these antibodies was 
increased and about half of the rabbits receiving this preparation for a prolonged period showed slight inflammation of the renal glomeruli. Wehner reported that glomerular inflammation is indicative of an antigen-antibody reaction in the glomerular basement membrane [18].

While Schlichtkrull et al. [1] asserted that MCinsulin was nonantigenic, another group have reported the production of antibodies by this preparation [4]. We proposed that the production of desamido-insulin during storage might be implicated in this antigenicity. We therefore prepared hexadesamido-insulin, which is structurally the most different from true insulin of the 63 desamido-insulin isomers, and $50 \%$ mono-desamido-insulin which may be generated during inappropriate storage of MC-insulin. The administration of these artificial preparations did not, however, result in the production of IgG antibodies.

It is of interest that the production of insulin $\mathrm{IgE}$ antibody detected by skin reaction was increased in animals receiving PB-C or PHD-I when, instead of $\mathrm{MC}$-insulin, the challenging antigen was the same as that used for sensitisation. This finding suggests that these preparations may be antigenic and produce reagin-type antibodies. Ito and Momoi recently suggested this possibility for porcine b-component [17].

Porcine hexa-desamido-insulin is similar to insulin in its amino acid composition and cannot be regarded as a heterogenous protein. It is though possible that it may have a different structure from true insulin. Our observation that PHD-I could produce reagin-type antibodies suggests that changes in the structure of insulin, particularly the steric structure, may promote antibody production.

Our results suggest that, if pharmaceutical preparations containing porcine b-component or porcine hexa-desamido-insulins are administered to humans, insulin allergy may result. It is concluded that the purity and storage conditions of insulin may be important factors in its antigenicity.

Acknowledgements. We would like to thank Dr. Shoichi Nakagawa of the Second Department of Internal Medicine of Hokkaido University for his measurement of the IgG antibodies and to Dr. Shinichi Ito of the First Department of Internal Medicine, Tokyo Medical and Dental University for the experiments on the reagintype of antibodies.

Insulin preparations were kindly provided by the Novo Research Institute, Copenhagen, Denmark.

\section{References}

1. Schlichtkrull J, Brange J, Christiansen AH, Hallund O, Heding LG, Jørgensen KG (1972) Clinical aspects of insulin antigenicity. Diabetes 21: 649-656

2. Mirouze J, Orsetti A, Schmouker Y, Carty E, Almes N (1973)
Treatment of diabetes mellitus with purified insulin. Nouv Presse Med 25: 1981-1985

3. Graber D, Fankhauser S (1978) Antigenicity of some, new, chromatographically purified, depot insulins. Schweiz Med Wochenschr 108: 1807-1809

4. Yue DK, Turtle JR (1975) Antigenicity of "monocomponent" pork insulin in diabetic subjects. Diabetes 24: 625-632

5. Kasama T, Iwata Y, Okubo T, Sakaguchi Y, Sugiura M (1980) Determination of purity and identification of animal source of insulin in various insulin preparations. Jpn J Pharmacol 30: 293-300

6. Patterson R, Lucena G, Metz R, Roberts M (1969) Reaginic antibody against insulin: Demonstration of antigenic distinction between native and extracted insulin. J Immunol 103: 1061-1071

7. Tada T (1975) Regulation of reaginic antibody formation in animals. Prog Allergy 19: 122-194

8. Sundby F (1962) Separation and characterization of acidinduced insulin transformation products by paper electrophoresis in $7 \mathrm{M}$ urea. J Biol Chem 237: 3406-3411

9. Kasama T, Uchida $M$, Yonezawa S, Tamura N, Yokoi K (1976) A study on monocomponent insulin III. The purity and stability of pharmaceutical preparations. J Jpn Diab Soc 19: 680-691 (in Japanese)

10. Weber K, Pringle JR, Osborn M (1972) Measurement of molecular weight by electrophoresis on SDS-acrylamide gel. In: Colowich SP, Kaplan NO (eds) Methods in enzymology, vol 26. Academic Press, New York, pp 3-17

11. Moore S, Stein WH (1963) Chromatographic determination of amino acids by the use of automatic recording equipment. In: Colowich SP, Kaplan NO (eds) Methods in enzymology, vol 6. Academic Press, New York, pp 819-831

12. Chibnall AC, Mangan JL, Ress MW (1958) Studies on the amide and $\mathrm{C}$-terminal residues in proteins. 2 . The ammonia nitrogen and amide nitrogen of various native protein preparations. Biochemistry 68 : 111-114

13. Kawamura T (1976) Insulin injection. In: Society of Japanese Pharmacopoeia (ed) Pharmacopoeia of Japan IX. Hirokawa Publishing Co, Tokyo, C-197 (in Japanese)

14. Asahina M (1976) Determination of melting point. In: Society of Japanese Pharmacopoeia (ed) Pharmacopoeia of Japan IX. Hirokawa Publishing Co, Tokyo, B-247 (in Japanese)

15. Ovary $Z$ (1958) Immediate reactions in the skin of experimental animals provoked by antibody antigen interactions. Prog Allergy 459-508

16. Nakagawa S, Nakayama H, Sasaki T, Yoshino K, Yu YY, Shinozaki K, Aoki S, Mashimo K (1973) A simple method for the determination of serum free insulin levels in insulintreated patients. Diabetes 22: 590-600

17. Ito S, Momoi H (1979) Studies on insulin allergy: Production of insulin IgE antibody in rats and comparison of insulin components. Jpn J Allergol 28: 31-39

18. Wehner $H$ (1976) The influence of insulin and insulin antibodies on the glomerular structure. Acta Endocrinol 83: 241-253

19. Rantz LA, Randall E (1945) A modification of the technic for determination of the antistreptolysin titer. Proc Soc Exp Biol Med 59: 22-25

Received: 3 June 1980

and in revised form: 18 December 1980

Toshio Kasama Ph. D.

Research Laboratories of Biological Science

Kodama Limited

957, Wanagaya Matsudo

Chiba, Japan 271 